\title{
StRESS HYPERGLYCEMIA RATIO AS A MARKER OF DISEASE SEVERITY IN HOSPITALIZED PATIENTS WITH ACUTE PYELONEPHRITIS
}

Francisco Sousa Santos; Margarida Fonseca²; Ana Pãosinho²; Inês Cruz²; João Sequeira Duarte; Clotilde Gouveia'; Alberto Mello e Silva²; Carlos Vasconcelos $^{1}$ Endocrinology (1) and Internal Medicine (2) Departments, Egas Moniz Hospital, Centro Hospitalar Lisboa Ocidental.

\section{Objectives}

Hyperglycemia has been been associated with worse outcomes in hospitalized patients with a variety of diseases, namely critical illness. It's been recently proposed that a relative hyperglycemia ratio - Stress Hyperglycemia Ratio (SHR) - might be even better associated with disease outcomes. We studied how SHR correlated with various morbidity parameters in hospitalized patients due to acute pyelonephritis.

\section{Methods}

- We conducted a retrospective study in a Portuguese central hospital, including every patient admitted to Medicine or Endocrinology wards with the main diagnosis of acute pyelonephritis (which had HbA1c measured during the stay) between 2012 and 2015.

- SHR was calculated as admission glycemia $(\mathrm{mg} / \mathrm{dL})$ divided by estimated average glucose derived from HbA1c.

- We assessed the duration of the hospital stay, analytical markers (such as estimated glomerular filtration rate - eGFR - at admission) and Systemic Inflamatory Response Syndrome (SIRS) criteria at admission.

\section{Results}

- A total of 57 patients (71,9\% female) were included, with a mean age of 76,7 years old.

- $77,2 \%$ had the diagnosis of Type 2 Diabetes and all the remainder were non-diabetic.

- $\quad 45,6 \%$ had sepsis criteria (presumed infection and $\geq 2$ SIRS criteria).

- The mean duration of hospital stay was 12,4 days. 2 deaths were registered.

\begin{tabular}{|l|c|c|c|}
\hline & Mean & Minimum & Maximum \\
\hline Age (years) & 76,9 & 38 & 91 \\
\hline Glycemia $(\mathrm{mg} / \mathrm{dL})$ & 171,8 & 78 & 367 \\
\hline HbA1c $(\%)$ & 7,3 & 4,5 & 14 \\
\hline SHR & 1,1 & 0,3 & 3,1 \\
\hline PCR $(\mathrm{mg} / \mathrm{dL})$ & 17,6 & 1 & 28 \\
\hline eGFR (CKD EPI formula) $\left(\mathrm{mL} / \mathrm{min} / 1.73 \mathrm{~m}^{2}\right)$ & 57,6 & 5 & 102 \\
\hline Nr. SIRS criteria & 1,48 & 0 & 4 \\
\hline Lenght of hospital stay (days) & 12,8 & 3 & 96
\end{tabular}

\begin{tabular}{|l|c|c|c|c|c|c|c|} 
& Age (years) & $\begin{array}{c}\text { Nr. of SIRS } \\
\text { criteria }\end{array}$ & $\begin{array}{c}\text { Lenght of Hospital } \\
\text { stay (days) }\end{array}$ & $\begin{array}{c}\text { Nr. of discharge } \\
\text { diagnosis }\end{array}$ & $\begin{array}{c}\text { PCR at } \\
\text { admission }\end{array}$ & N/S \\
(CKD EPI formula)
\end{tabular}

Pearson correlation coefficients between various variables. N/S - not significant. * $-p<0.05$

- After adjusting for age, sex and diabetes presence, SHR (but not glycemia) correlated positively - correlation coefficient= 0,908 - with the number of SIRS criteria $(p=0.033)$.

\section{Conclusion}

SHR, which takes into account background glycemia rather than absolute glycemia alone, might be a biomarker of disease severity in case of patients hospitalized with acute pyelonephritis, irrespective of being diabetic or not. Given this was a retrospective study and sample size was rather small, further studies are needed to confirm this hypothesis and to assess SHR relation with clinical outcomes, namely mortality.

\section{Bibliography}

1- Roberts GW et al. Relative Hyperglycemia, a Marker of Critical Illness: Introducing the Stress Hyperglycemia Ratio. J Clin Endocrinol Metab. 2015 Dec; 100(12):4490-7.

2 - Umpierrez G, Isaacs S, Niloofar B, You X, Thaler LM, Kitabchi AE. Hyperglycemia: an independent marker of in- hospital mortality in patients with undiagnosed diabetes. J Clin Endocrinol Metab. 2002; 87:978-982.

3 - Krinsley J. Association between hyperglycemia and increased hospital mortality in a heterogeneous population of critically ill patients. Mayo Clin Proc. 2003; 78:1471-1478.

4 - Baker E, Janaway C, Philips B, Brennan AL, Baines DL, Wood DM, Jones PW. Hyperglycemia is associated with poor outcomes in patients admitted to hospital with acute exacerbations of chronic obstructive pulmonary disease. Thorax. 2006;61:284-289. 